\title{
Impacts of Climate Variability and Change on Rainfed Sorghum and Maize: Implications for Food Security Policy in Tanzania
}

\author{
Barnabas M. Msongaleli ${ }^{1}$, Filbert Rwehumbiza ${ }^{2}$, Siza D. Tumbo ${ }^{3} \&$ Nganga Kihupi ${ }^{3}$ \\ ${ }^{1}$ Department of Geography and Environmental Studies, School of Social Sciences, University of Dodoma, \\ Dodoma, Tanzania \\ ${ }^{2}$ Department of Soil Science, Sokoine University of Agriculture, Morogoro, Tanzania \\ ${ }^{3}$ Department of Agricultural Engineering and Land Planning, Sokoine University of Agriculture, Morogoro, \\ Tanzania
}

Correspondence: Barnabas M. Msongaleli, Department of Geography and Environmental Studies, School of Social Sciences, University of Dodoma, P. O. Box 359 Dodoma, Tanzania. Tel: 255-754-821-636. E-mail: bmsongaleli@yahoo.co.uk

Received: December 14, 2014 Accepted: March 11, 2015 Online Published: April 15, 2015

doi:10.5539/jas.v7n5p124 URL: http://dx.doi.org/10.5539/jas.v7n5p124

\begin{abstract}
Concern about food security has increased because of a changing climate, which poses a great threat to food crop productivity. Climate change projections from the Coupled Model Inter-comparison Project phase 5 (CMIP5) and crop models were used to investigate the impacts of climate change on rain-fed cereal production. Calibrated and evaluated crop models simulated maize and sorghum yields over time periods and scenarios across central zone Tanzania with and without adaptation. Simulation outputs without adaptation showed predominant decrease and increase in maize and sorghum yields, respectively. The results showed that maize yields were predicted to decline between $1 \%$ and $25 \%$ across periods, representative concentration pathways (RCPs) and global circulation models (GCMs). However, sorghum yields were on average predicted to increase between $5 \%$ and $21 \%$. Overall when adaptation is incorporated toward mid-century, yields are projected to increase for both crops. The yield projections variation between cereal crops highlights the importance of location and crop specific climate change impact assessments. Despite the uncertainties in predicting the impacts of climate change on rainfed crops, especially on cereals (maize and sorghum) which are important staple food crops in semi-arid Tanzania, the findings of this study enable policy makers to develop plans aimed at sustainable food security. In conclusion, the results demonstrate the presumption that sorghum productivity stands a better chance than maize under prospects of negative impacts from climate change in central zone Tanzania.
\end{abstract}

Keywords: agronomic adaptation, cereals, climate change, policy, simulation modeling, uncertainty

\section{Introduction}

Although several studies project the net effect of climate change on cereal yields to be negative in sub-Saharan Africa (SSA), the direction of yield change in any given area depends on the physiology of the crop concerned and the current climatic condition under which it is grown because different species have different base and optimum temperatures for development (Porter \& Semenov, 2005; Lobell et al., 2008; Challinor et al., 2014). Rainfall projections from an assessment of 12 CMIP3 (AR4) GCMs over eastern Africa suggest an increase in rainfall by the end of the $21^{\text {st }}$ Century (Shongwe, van Oldenborgh, van den Hurk, \& van Aalst, 2011; IPCC, 2013), though confounded by extreme precipitation changes (droughts and heavy rainfall) during the last 30-60 years (Williams \& Funk, 2011; Lyon \& DeWitt, 2012). Rainfall projections for Tanzania appear consistent with those of eastern Africa, which indicate increase in annual rainfall with the ensemble range spanning changes of -4 to $+30 \%$ by the 2090 s (McSweeney, New, \& Lozano, 2010). However, rainfall projections data from CMIP5 (Taylor, Stouffer, \& Meehl, 2012) used in the Fifth Assessment Report (AR5) escalate the uncertainty in that, while overall rainfall is projected to increase by $9 \%$ for central Tanzania as observed by Wambura, Ngongolo, Mlonganile, Sangalugembe, and Tumbo (2014), analyses by Taylor et al. (2013) of both the Fourth Assessment Report (AR4) and AR5 multi-model ensembles attributed the projected increases to extreme monthly rainfall rather than changes to mean rainfall. Previous studies had indicated a decline in rainfall in future for central areas 
of Tanzania (Paavola, 2003; Matari, Chang'a, Chikojo, \& Hyera, 2008).

Because of the uncertainties in processes underpinning the changing climate especially on rainfall projections, more research is needed to understand the influence of the projections on crop production on local conditions. Information is required to enable an understanding of how the projected changes in climate will impact smallholder dryland farmers who need to strategically respond and adapt to the ill-effects of changing climate (Hatfield et al., 2011; Rurinda et al., 2014). It is due to this wide range of projections and the possible impacts on crop production at different scales and over different time periods that detailed studies are needed, because the underlying uncertainties exacerbate concerns about food security and impede decision making on food security policy and climate change issues (Ingram, Gregory, \& Izac, 2008; Thornton, Jones, Ericksen, \& Challinor, 2011; Yao, Qin, Zhang, Lin, \& Boken, 2010).

Overall, although rainfall projections in eastern Africa depict a glimpse of hope regarding possible impacts on crop productivity (Doherty, 2009), other studies indicate contrasting conclusions, such as enhanced crop yields or no change in crop yields (Kurukulasuriya \& Mendelsohn, 2008) and yield decreases (Thornton, Jones, Alagarswamy, \& Andresen, 2009). Other studies in SSA show some evidence of negative climate change impact on crop yield for major staple cereal food crops like maize, sorghum and millet (Schlenker \& Lobell, 2010; Knox, Hess, Daccache, \& Wheeler, 2012; Berg, De Noblet-Ducoudre, Sultan, Lengaigne, \& Guimberteau, 2013; Zinyengere, Crespo, \& Hachigonta, 2013; Waha, Müller, \& Rolinski, 2013). These studies give generalized and broad conclusions about the impact of climate change which are not manifest in crop production to address increased food security concerns. In Tanzania, in particular, several studies indicate that maize production is projected to decline in the future (Mwandosya, Nyenzi, \& Luhanga, 1998; Arndt, Farmer, Strzepek, \& Thurlow, 2011; Rowhani, Lobell, Linderman, \& Ramankutty, 2011; Kilembe, Thomas, Waithaka, Kyotalimye, \& Tumbo, 2013).

The projected yields of crops under a range of climate scenarios, however, suffer from the limitations associated with the difficulty in obtaining data on local conditions or crop characteristics (Ruane et al., 2013, Watson \& Challinor, 2013; Thornton, Jones, Alagarswamy, Andresen, \& Herrero, 2010); uncertainties in climate data (e.g. Ramirez-Villegas, Challinor, Thornton, \& Jarvis, 2013) and uncertainties in crop models' processes (Ainsworth, Leaky, Ort, \& Long, 2008). Currently, however, the weaknesses with regard to data availability and uncertainties are addressed in the methodological procedures of the Agricultural Model inter-comparison and Improvement Project (AgMIP) through aggregation of geographic data regarding the spatial distribution of climate (daily weather), topography, soils, land-use, farm-level management, socioeconomic conditions, and reported yields (Rosenzweig et al., 2013a, 2013b). Moreover, the use of statistical methods to evaluate and understand uncertainty in the outputs of climate change impacts has been recognized as it enhances drawing of robust conclusions regarding model applications (Falloon et al., 2014).

Due to high dependence on rain-fed agriculture in Tanzania, it is clear that smallholder farmers are sensitive to possible adverse changes in climate and they are faced with the question of how to adapt to climate change. Therefore, they need information on the potential impact of climate change for the next few decades. Recent studies have established that an undertaking of climate change impact assessments at local scales is essential as it allows exploration of local agronomic management practices and their incorporation into adaptation strategies formulation (Zinyengere, Crespo, Hachigonta, \& Tadross, 2014). In Tanzania, there is paucity of information on impacts of climate change on sorghum and maize though studies elsewhere seem to suggest that impacts on sorghum are predicted to be less significant compared to maize. For example, according to Lobell et al. (2008) maize yield in Southern Africa is projected to decline by about $30 \%$ compared with a decrease of only $2 \%$ for sorghum by 2030 . Other studies show that sorghum will increase by a range of 19 to $72 \%$ across eastern and southern Africa (Zinyengere et al., 2014; Turner \& Rao, 2013).

Detailed crop simulation studies at various scales are required due to spatial variability of climate especially rainfall, in order to provide relevant knowledge on impacts and for evaluating possible adaptation options under farm and policy levels (Thompson, Berrang-Ford, \& Ford, 2010; White, Hoogenboom, Kimball, \& Wall, 2011). The use of multiple-models in climate change assessment has shown to enhance the quantification of uncertainties, as different models differ in structure and parameter values (Rötter, Carter, Olesen, \& Porter, 2011). A significant proportion of uncertainty in climate impact projections has been attributed to variations among crop models (Asseng et al., 2013). In this study the Agricultural Production Systems sIMulator (APSIM) and Decision Support System for Agrotechnology Transfer (DSSAT) crop models were used to quantify impacts of climate variability and change on rainfed sorghum and maize productivity across five locations having contrasting soil properties and crop management practices. The specific objectives were; first, to link APSIM and DSSAT with GCMs to simulate rainfed sorghum and maize production under the CMIP5; 
second, to simulate scenarios representing some agronomic strategies feasible under conditions of dryland farming to provide insight into their potential for adaptation; and third to evaluate uncertainty in climate change impacts on sorghum and maize in order to provide relevant information to policy makers and others.

\section{Methods}

\subsection{Description of the Study Area}

Central Tanzania (Singida and Dodoma regions) has been identified as one of livelihood zones based on FAO (Figure 1). The zone is designated as "sorghum-livestock" and is most relevant to sorghum production. The central regions account for three-quarters of Tanzania's 500,000 to 800,000t annual sorghum harvests. The zone is one of the most sensitive to climate variability and change mainly owing to temperature and rainfall variability. Soils in this zone are mainly sandy and loamy of low fertility and seasonally waterlogged or flooded pockets of clays. Weather stations at five (5) locations were identified from which weather data for running crop simulation models were obtained (Table 1). Observed maize and sorghum yields across the zone were obtained from the Tanzania National Panel Survey (TNPS) of 2010-2011 (NBS, 2012) for the 2009/10 season.

Table 1. Geographical locations and rainfall characteristics of five weather stations in study area

\begin{tabular}{lllllll}
\hline Station & Latitude & Longitude & Altitude (m.a.s.l) & Annual rainfall (mm) & JFM (mm) & OND (mm) \\
\hline Mpwapwa & -6.2 & 36.30 & 1007 & 584 & 330 & 183 \\
Dodoma & -6.167 & 35.67 & 1118 & 567 & 366 & 107 \\
Hombolo & -5.75 & 35.95 & 1062 & 627 & 379 & 180 \\
Singida & -4.48 & 34.45 & 1377 & 797 & 419 & 228 \\
Manyoni & -5.44 & 34.50 & 1245 & 695 & 385 & 222 \\
\hline
\end{tabular}

Note. m.a.s.l = metres above sea level; JFM = January February March; OND = October November December.

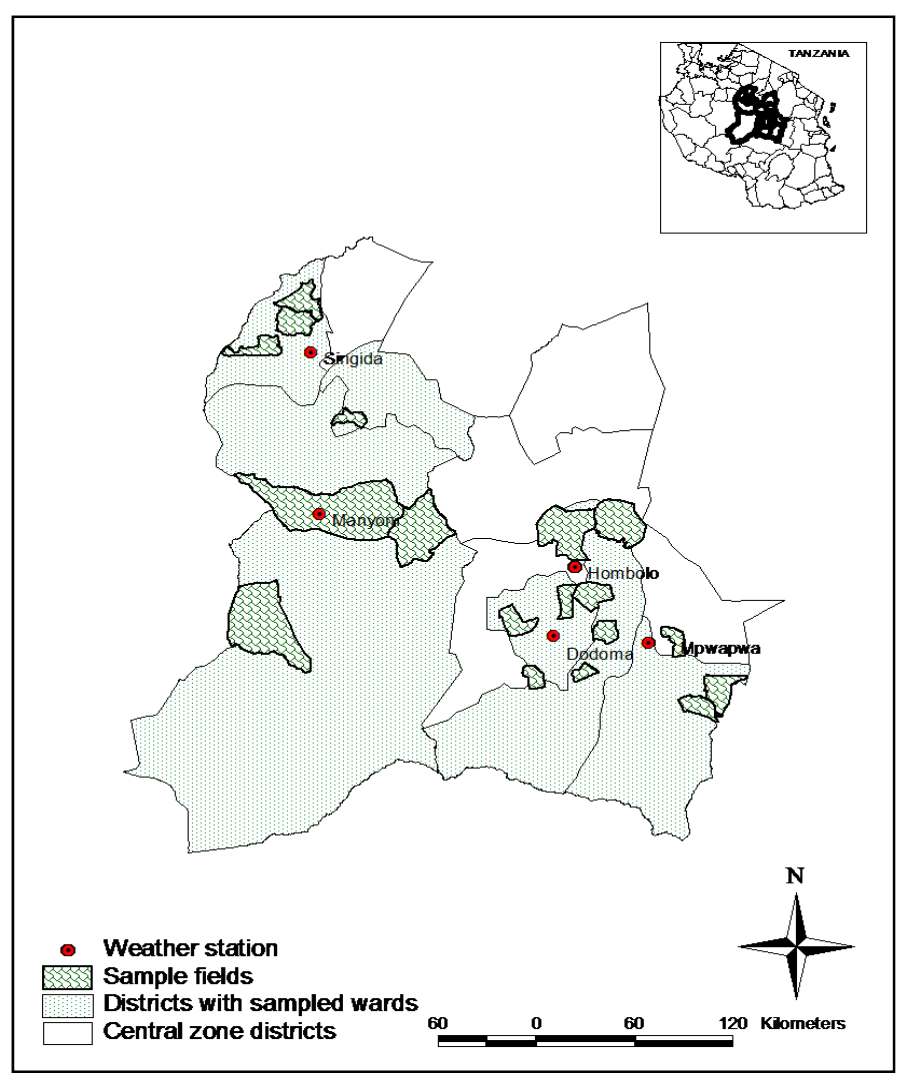

Figure 1. Map showing locations of fields with reported sorghum and maize yields used in model evaluation 


\subsection{Model Description, Calibration and Evaluation}

Calibration and evaluation of APSIM (Keating et al., 2003) model used in this study was done based on experimental data for two growing seasons. APSIM model was evaluated for simulation of days after sowing to flowering and maturity, dry matter accumulation (biological yield) and grain yield. Genetic coefficients used by APSIM and DSSAT for sorghum are shown in Tables 2 and 3, respectively. Data for calibrating and evaluating both models for maize (Situka variety) were obtained from literature (Mourice et al., 2014).

Table 2. Crop parameters in APSIM for three sorghum varieties

\begin{tabular}{lllllll}
\hline Parameter & & Source & Units & Macia & Tegemeo & Pato \\
\hline Thermal time accumulation & End of juvenile phase to panicle initiation & $\mathrm{C}$ & ${ }^{\circ} \mathrm{C}$ day & 230 & 270 & 275 \\
& Flag stage to flowering & $\mathrm{C}$ & ${ }^{\circ} \mathrm{C}$ day & 195 & 170 & 175 \\
& Flowering to start of grain filling & $\mathrm{C}$ & ${ }^{\circ} \mathrm{C}$ day & 80 & 80 & 100 \\
& Flowering to maturity & $\mathrm{C}$ & ${ }^{\circ} \mathrm{C}$ day & 675 & 760 & 760 \\
& Maturity to seed ripening & $\mathrm{L}$ & ${ }^{\circ} \mathrm{C}$ day & 1 & 1 & 1 \\
\hline Photoperiod & Day length photoperiod to inhibit flowering & $\mathrm{D}$ & $\mathrm{H}$ & 11.5 & 11.5 & 11.5 \\
& Day length photoperiod for insensitivity & $\mathrm{D}$ & $\mathrm{H}$ & 13.5 & 13.5 & 13.5 \\
& Photoperiod slope & $\mathrm{L}$ & ${ }^{\circ} \mathrm{C} / \mathrm{h}$ & 0.01 & 0.01 & 0.01 \\
& Base temperature & $\mathrm{L}$ & ${ }^{\circ} \mathrm{C}$ day & 8 & 8 & 8 \\
& Optimum temperature & $\mathrm{D}$ & ${ }^{\circ} \mathrm{C}$ day & 30 & 30 & 30
\end{tabular}

Note. C: calibrated; D: Default; L: literature; O: observed.

Table 3. Genetic coefficients in DSSAT for three sorghum varieties

\begin{tabular}{|c|c|c|c|c|}
\hline Coefficient & Definition & Macia & Tegemeo & Pato \\
\hline TBASE & Base temperature below which no development occurs, ${ }^{\circ} \mathrm{C}$ & 8.0 & 8.0 & 8.0 \\
\hline TOPT & Temperature at which maximum development rate occurs during vegetative stages ${ }^{\circ} \mathrm{C}$ & 34.0 & 34.0 & 34.0 \\
\hline ROPT & Temperature at which maximum development rate occurs for reproductive stages ${ }^{\circ} \mathrm{C}$ & 34.0 & 34.0 & 34.0 \\
\hline P1 & $\begin{array}{l}\text { Thermal time from seedling emergence to the end of the juvenile phase (expressed in } \\
\text { degree days above a base temperature of } 8^{\circ} \mathrm{C} \text { ) during which the plant is not } \\
\text { responsive to changes in photoperiod. }\end{array}$ & 300 & 440 & 460 \\
\hline $\mathrm{P}_{2} \mathrm{O}$ & $\begin{array}{l}\text { Critical photoperiod or the longest day length (in hours) at which development occurs } \\
\text { at a maximum rate. At values higher than P20, the rate of development is reduced. }\end{array}$ & 12.5 & 12.5 & 12.5 \\
\hline $\mathrm{P}_{2} \mathrm{R}$ & $\begin{array}{l}\text { Extent to which phasic development leading to panicle initiation (expressed in degree } \\
\text { days) is delayed for each hour increase in photoperiod above P } 20 \text {. }\end{array}$ & 1 & 1 & 1 \\
\hline P5 & $\begin{array}{l}\text { Thermal time (degree days above a base temperature of } 8^{\circ} \mathrm{C} \text { ) from beginning of grain } \\
\text { filling ( } 3-4 \text { days after flowering) to physiological maturity. }\end{array}$ & 520.0 & 650.0 & 650.0 \\
\hline G1 & Scaler for relative leaf size. & 15 & 15 & 15 \\
\hline G2 & Scaler for partitioning of assimilates to the panicle (head). & 6.5 & 6.0 & 6.0 \\
\hline PHINT & $\begin{array}{l}\text { Phylochron interval; the interval in thermal time (degree days) between successive } \\
\text { leaf tip appearances. }\end{array}$ & 49.0 & 49.0 & 49.0 \\
\hline
\end{tabular}

\subsection{Crop Management and Soil Input Data}

Macia sorghum variety was chosen for subsequent analyses because it is high-yielding with early maturity, and currently highly preferred by smallholder farmers. Similarly, Situka maize variety was chosen based on its early maturity and tolerance to low nitrogen typical of the study area farm characteristics. Crop management 
information including planting dates, plant population, varieties used, organic and inorganic fertilizer use, intercropping and measured yields, were obtained through key informants structured interview and augmented by the information from TNPS. This information was used in the construction of a farm survey template as per AgMIP protocols (Rosenzweig et al., 2013b). For the current analysis, a sample of 63 fields planted with maize and 48 fields planted with sorghum were extracted from the database (based on available reported yields), to construct farm survey template in central Tanzania. A Quick and Dirty [File Translation] User Interface (QUADUI) tool (http://www.agmip.org/tools) was used to translate the templates into ready model run files for the simulations.

Soil profile data used to parameterize soil modules within APSIM and DSSAT were mainly extracted from available databases e.g. Africa Soil Information Service (AfSIS) (Leenaars, 2012) and WISE (2008), but also data from freshly dug soil profiles were used. A total of 5 soil profiles were identified to represent variable soils available within central Tanzania. Considering the variability of soils across farms, the soil profiles were deliberately subdivided to capture the soil quality based on increasing or decreasing the amount of organic carbon and amount of available water by $20 \%$ as described in the AgMIP Handbook (Rosenzweig et al., 2013b). The subdivisions resulted in a total of 15 soil profiles with classes of poor, average and good quality soils. A range of analytical data for soil profiles used in the models is presented in Table 4.

Table 4. Range of soil analytical data for soil profiles used in simulations

\begin{tabular}{lllllllll}
\hline $\begin{array}{l}\text { Depth of } \\
\text { bottom }(\mathrm{cm})\end{array}$ & Clay (\%) & Silt (\%) & $\begin{array}{l}\text { Organic } \\
\text { carbon }(\%)\end{array}$ & $\begin{array}{l}\mathrm{pH} \text { in } \\
\text { water }\end{array}$ & $\begin{array}{l}\text { Cation Exchange } \\
\text { Capacity }(\mathrm{cmol} / \mathrm{kg})\end{array}$ & $\begin{array}{l}\text { Lower Limit } \\
(\mathrm{LL})\left(\mathrm{cm}^{3} / \mathrm{cm}^{3}\right)\end{array}$ & $\begin{array}{l}\text { Drained upper limit } \\
(\mathrm{DUL})\left(\mathrm{cm}^{3} / \mathrm{cm}^{3}\right)\end{array}$ & $\begin{array}{l}\text { Saturation (SAT) } \\
\left(\mathrm{cm}^{3} / \mathrm{cm}^{3}\right)\end{array}$ \\
\hline $15-25$ & $13-55$ & $6-20$ & $0.35-1.26$ & $5.4-5.9$ & $12.8-24.2$ & $0.077-0.355$ & $0.128-0.441$ & $0.349-0.499$ \\
$30-45$ & $9-59$ & $4-16$ & $0.24-0.76$ & $5.1-4.8$ & $9.0-22.1$ & $0.057-0.375$ & $0.108-0.454$ & $0.358-0.517$ \\
$46-80$ & $12-59$ & $2-18$ & $0.1-0.6$ & $4.5-4.8$ & $7.5-21.8$ & $0.102-0.386$ & $0.216-0.456$ & $0.324-0.508$ \\
$102-115$ & $9-55$ & $3-6$ & $0.04-0.49$ & $4.0-4.8$ & $6.8-23.0$ & $0.150-0.305$ & $0.362-0.441$ & $0.376-0.529$ \\
\hline
\end{tabular}

\subsection{Climate and Data Scenarios}

Climate change scenarios for near-term (2010-2039), mid-century (2040-2069) and end-century (2071-2099) periods were generated using $20 \mathrm{GCMs}$ from CMIP5 (Table 5) for two Representative Concentration Pathways (RCPs): RCP 4.5 and RCP 8.5 bias-corrected using the method of Hempel et al. (2013). The simulations were performed for the three climate change scenarios using data from all 20 GCMs. Moreover, climate data of five GCMs namely: CCSM4, GFDL-ESM2M, HadGEM2-ES, MIROC5, and MPI-ESM-MR, were separately analysed for mean changes in projected climate compared with baseline (1980-2010). These GCMs were selected due to their long history of development and evaluation, a preference for higher resolution, and established performance in monsoon regions (Rosenzweig et al., 2013b).

RCPs usually refer to the portion of the concentration pathway extending up to 2100 , for which Integrated Assessment Models have produced corresponding emission scenarios (IPCC, 2013). The RCP8.5 is a high emissions scenario, corresponding to projections of high human population (12 billion by 2100), high rates of urbanization and limited rates of technological change, all resulting in emissions approaching $30 \mathrm{Gt}$ of carbon by 2100 compared with 8Gt in 2000 (Riahi et al., 2007). The RCP4.5 scenario is an intermediate mitigation scenario characterized by continuously increasing human population but at a rate lower than in the RCP8.5 scenario, intermediate levels of economic development and less rapid and more diverse technological change (Moss et al., 2010).

\subsection{Evaluation of Adaptation Options}

According to NAPA (URT, 2007) potential adaptation measures include adjustments in management practices such as planting density, fertilizer application and planting date. Planting densities above those currently practised by smallholder dryland farmers were adopted assuming improvement in extension services and farmers' reception and adoption of improved agricultural technologies. Planting density and fertilizer application were combined with two planting dates as agronomic management scenarios for each crop (Table 6). The selected agronomic management scenarios were based on local expert recommendations under conditions of central Tanzania and affordability by the local farmers. These were obtained from agricultural reports in respective districts. Fertilizer amounts are those recommended by experts for the low-input systems 
predominant in semi-arid areas of Tanzania. An early planting date (EP) corresponds to onset of rains, which have shown early trends and a late planting date (LP) serves to test the possibility of shifts of rainfall pattern in the future.

Table 5. Coupled Model Intercomparison Project phase 5 (CMIP5) general circulation models considered in this study

\begin{tabular}{|c|c|c|c|c|c|c|}
\hline & Modelling centre & Country & Model & Lat. & Lon. & Res. \\
\hline $\mathrm{i}$ & $\begin{array}{l}\text { Commonwealth Scientific and Industrial Research Organisation/Bureau of } \\
\text { Meteorology (CSIRO-BOM) }\end{array}$ & Australia & ACCESS 1.0 & 1.87 & 1.25 & MR \\
\hline ii & Beijing Climate Centre, China Meteorological Administration & China & BCC-CSM1.1 & 2.81 & 2.79 & LR \\
\hline iii & $\begin{array}{l}\text { College of Global Change and Earth System Science, } \\
\text { Beijing Normal University }\end{array}$ & China & BNU-ESM & 2.81 & 2.79 & LR \\
\hline iv & $\begin{array}{l}\text { Community Climate System Model, Climate and Global Dynamics } \\
\text { Division/ National Centre for Atmospheric Research }\end{array}$ & USA & CCSM4 & & & \\
\hline $\mathrm{v}$ & $\begin{array}{l}\text { Community Earth System Model, Climate and Global Dynamics Division/ } \\
\text { National Centre for Atmospheric Research }\end{array}$ & USA & CESM1-BGC & & & \\
\hline vi & $\begin{array}{l}\text { Commonwealth Scientific and Industrial Research Organisation/Queensland } \\
\text { Climate Change Centre of Excellence (QCCCE) }\end{array}$ & Australia & CSIRO-Mk3.6 & 1.87 & 1.87 & MR \\
\hline vii & Canadian Centre for Climate Modelling and Analysis & Canada & CanESM2 & 2.81 & 2.79 & LR \\
\hline viii & Geophysical Fluid Dynamics Laboratory & US-NJ & GFDL-ESM2G & 2.5 & 2.0 & LR \\
\hline ix & & US-NJ & GFDL-ESM2M & 2.5 & 2.0 & LR \\
\hline $\mathrm{x}$ & Met Office Hadley Centre & UK-Exeter & HadGEM2-CC & 1.87 & 1.25 & MR \\
\hline $\mathrm{xi}$ & & UK-Exeter & HadGEM2-ES & 1.75 & 1.25 & MR \\
\hline xii & Institut Pierre-Simon Laplace & France & IPSL-CM5A-LR & 3.75 & 1.89 & LR \\
\hline xiii & & & IPSL-CM5A-MR & 2.50 & 1.26 & LR \\
\hline xiv & $\begin{array}{l}\text { Atmosphere and Ocean Research Institute (University of Tokyo), National } \\
\text { Institute for Environmental Studies and Japan Agency for Marine-Earth } \\
\text { Science and Technology }\end{array}$ & Japan & MIROC-ESM & 2.81 & 2.79 & LR \\
\hline $\mathrm{xv}$ & & Japan & MIROC5 & 1.40 & 1.40 & HR \\
\hline xvi & Max Planck Institute for Meteorology (MPI-M) & Germany & MPI-ESM-LR & 1.87 & 1.87 & MR \\
\hline xvii & & Germany & MPI-ESM-MR & 1.87 & 1.87 & MR \\
\hline xviii & Meteorological Research Institute & Japan & MRI-CGCM3- & 1.12 & 1.12 & HR \\
\hline xix & Norwegian Climate Centre & Norway & Nor-ESM1-M & 2.50 & 1.89 & LR \\
\hline $\mathrm{xx}$ & Institute for Numerical Mathematics & Russia & INM-CM4 & 2.0 & 1.5 & MR \\
\hline
\end{tabular}

Table 6. Agronomic management scenarios for maize and sorghum

\begin{tabular}{llll}
\hline \multirow{2}{*}{ Crop } & \multicolumn{3}{c}{ Management } \\
\cline { 2 - 4 } & Planting density (Plants/ha) & Fertilizer Application (kg N/ha) & Dates (period) of planting \\
\hline Maize & 33,000 & 40,60 & $\begin{array}{l}\text { Early: Early-mid December } \\
\text { Late: Early-mid January } \\
\text { Sorghum }\end{array}$ \\
& 90,000 & 20,40 & Early: Early-mid December \\
& & & Late: Early-mid January \\
\hline
\end{tabular}

\subsection{Uncertainty and Confidence Assessment}

Uncertainty in the projected impact of climate change on crops was assessed through two measures namely, sign of mean yield change and comparison of interannual yield variability using coefficients of variation (CV), similar to methods used by Ruiz-Ramos and Minguez (2010) and Zinyengere et al. (2014). The sign of mean yield change was determined for each crop, crop model, GCM and RCP. Coincidence of GCMs and crop models with the same sign of change across RCP was used to ascertain the degree of confidence in the direction of yield change. Mean CVs were compared for GCMs and RCPs, thereby identifying the sources of 
large uncertainty through high interannual variability.

\section{Results and Discussion}

\subsection{Climate Change Projections}

Climate models consistently projected increased temperatures for selected weather stations in the Central zone of Tanzania. Projected temperature changes showed a mean increase in the range of $1.4-2.8{ }^{\circ} \mathrm{C}$ (Table 7). Dodoma station showed both the highest projected mean increase in temperature, recorded under the HADGEM2-ES $\left(2.8^{\circ} \mathrm{C}\right)$ and the lowest mean temperature increase with GFDL-ESM2M $\left(1.4^{\circ} \mathrm{C}\right)$. In contrast, the projected change in rainfall varied from one location to the other but consistently showing decline across all GCMs, except MIROC5, which showed an increase $+4.5-7.3 \%$ (Table 7). Projected mean rainfall changes were small, within a $-1.7 \%$ average, although varying considerably across GCMs. While projected rainfall changes were variable and uncertain, the projected temperature changes showed strong consistency with an upward trend.

Table 7. Mean change in projected climate between baseline (1980-2010) and future (2040-2069) periods for RCP 8.5

\begin{tabular}{llllll}
\hline \multirow{2}{*}{ Station } & GCM & \multicolumn{3}{c}{ Temperature $\left({ }^{\circ} \mathrm{C}\right)$} & Rainfall (\%) \\
\cline { 2 - 5 } Dodoma & Average & Minimum & Maximum & \\
& GCSM4 & 1.9 & 1.9 & 2.0 & -2.5 \\
& HADGEM2-ES & 1.4 & 1.7 & 1.2 & -8.5 \\
& MIROC5 & 2.8 & 2.9 & 2.8 & -1.4 \\
Manyoni & 2.2 & 2.1 & 2.4 & 7.3 \\
& MPI-ESM-MR & 2.4 & 2.4 & 2.5 & -0.4 \\
& CCSM4 & 1.9 & 1.8 & 2.0 & -8.9 \\
& GFDL-ESM2M & 1.8 & 1.8 & 1.7 & -3.0 \\
Singida & HADGEM2-ES & 2.7 & 2.6 & 2.8 & -5.2 \\
& MIROC5 & 2.3 & 2.1 & 2.4 & 7.0 \\
& MPI-ESM-MR & 2.3 & 2.1 & 2.4 & -0.2 \\
& CCSM4 & 1.9 & 1.8 & 1.9 & -10.3 \\
& GFDL-ESM2M & 1.8 & 1.8 & 1.7 & -1.9 \\
& HADGEM2-ES & 2.7 & 2.6 & 2.8 & -2.7 \\
& MIROC5 & 2.3 & 2.1 & 2.4 & 4.5 \\
& MPI-ESM-MR & 2.6 & 2.7 & 2.4 & -0.3 \\
\hline
\end{tabular}

\subsection{Model Evaluation and Crop Yield Projections}

Statistical indicators showing the simulation efficiency of APSIM model in simulating sorghum are shown in Table 8. Root mean square error (RMSE) which is an overall measure of model performance and compares the agreement of simulated versus observed values show a good response because the lower the values of RMSE the better the model in explaining most of the variations in the dataset. Moreover, data indicate that the simulated grain and biomass yield values reasonably matched observed values, owing to the agreement index (d-statistic) ranging from 0.6 to 0.9 across the varieties. The d-statistic values close to 1 are regarded as better simulations and according to these statistical indicators the model performance was deemed satisfactory. Simulated and observed (survey data) yields for the 2009/2010 season are shown in Figure 2. The models APSIM and DSSAT appear appropriate owing to the $\mathrm{R}^{2}$ values of 0.75 and 0.69 for maize and 0.82 and 0.61 for sorghum, respectively (Figure 2). The calibrated models were used to simulate maize and sorghum grain yields under the three scenarios (near-term, mid-century and end-century). 
Table 8. Statistical indicators of model performance

\begin{tabular}{|c|c|c|c|c|c|c|}
\hline \multirow{2}{*}{ Parameters/Cultivar } & \multicolumn{2}{|l|}{ Macia } & \multicolumn{2}{|c|}{ Tegemeo } & \multicolumn{2}{|l|}{ Pato } \\
\hline & RMSE (kg/ha) & d-Stat & RMSE (kg/ha) & d-Stat & RMSE (kg/ha) & d-Stat \\
\hline Grain yield & 133 & 0.73 & 87 & 0.62 & 140 & 0.60 \\
\hline Biomass & 178 & 0.93 & 418 & 0.66 & 236 & 0.83 \\
\hline
\end{tabular}

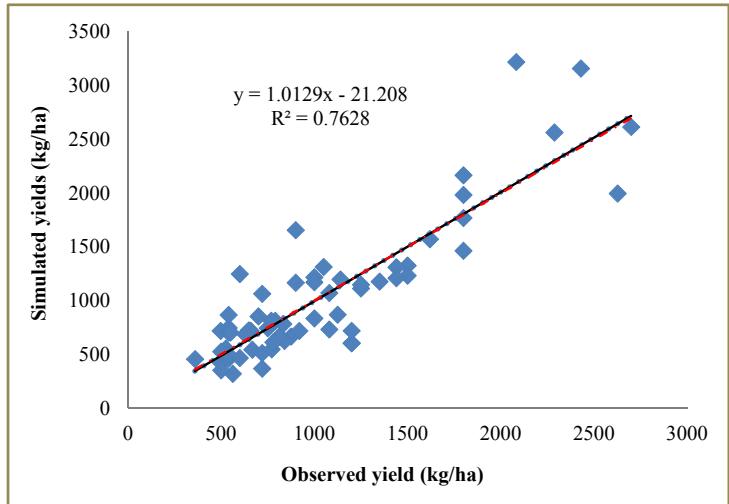

a

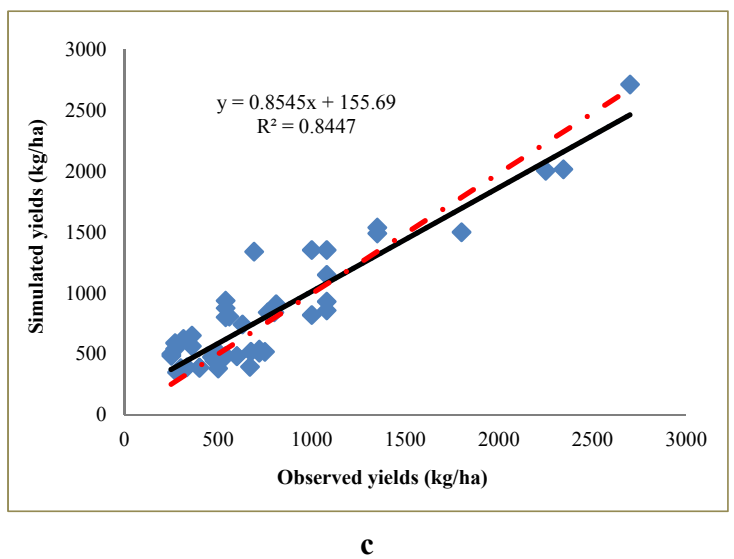

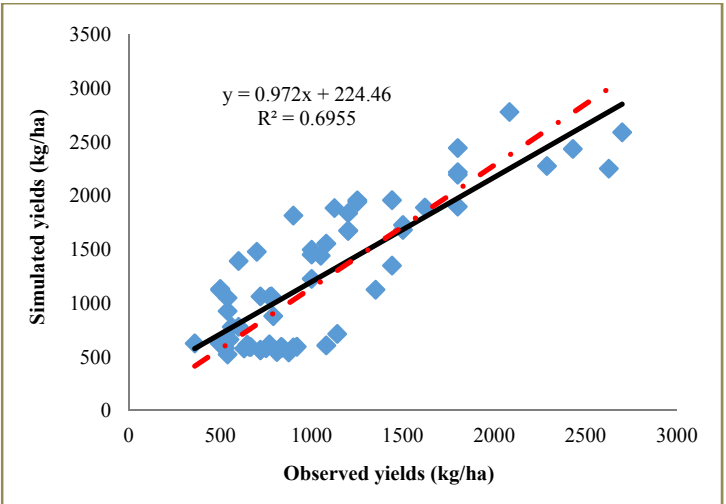

b

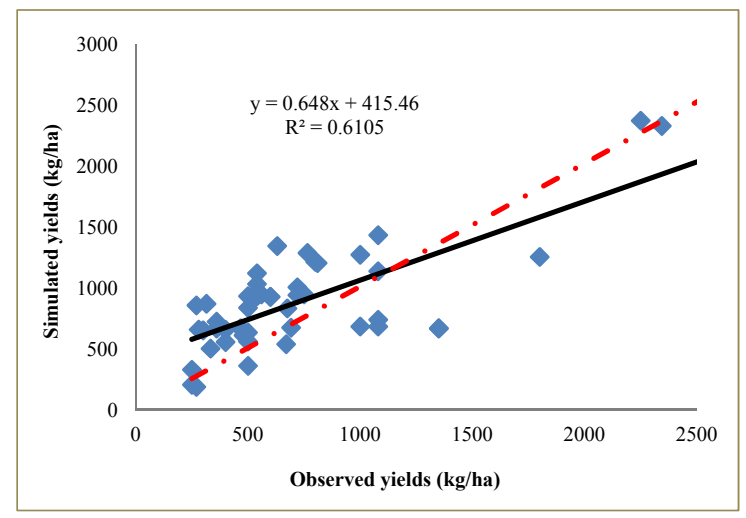

d

Figure 2. Relationship between simulated yields of maize (a \& b) and sorghum (c \& d) and reported yields for the season 2009-2010 (dashed line is 1:1)

Projected mean yield change showed a consistent decline for maize yields (Table 9). Average yield decline across all GCMs varied between $1 \%$ and $2.4 \%$ in the near term, between $3.7 \%$ and $7.1 \%$ towards mid-century and between $4.6 \%$ and $25.3 \%$ towards end of the century. In contrast, the projected sorghum yields show an increase varying between $5.4 \%$ and $6.9 \%$ in the near term, between $7.5 \%$ and $14.5 \%$ towards mid-century and between $5.7 \%$ and $20.7 \%$ towards end of the century (Table 10). The magnitude of yield change is higher in DSSAT than in APSIM. This is consistent to results by Rosenzweig et al. (2014) who reported model agreement on direction of yield change but varying in magnitude. Sultan et al. (2014) observed high consistence across climate and crop models in climate and impacts projections on sorghum between the western and eastern parts of the Sahel. In East Africa, a study by Thornton et al. (2009) similarly showed yield decreases for maize over the region ranging between $1 \%$ and $15 \%$ across emissions scenarios and climate models, largely as a result of temperature increase.

Increase in sorghum yields shown by almost all GCMs under both RCPs, may be attributed to increase in temperatures and the slight changes in projected rainfall which appear to create conducive conditions for sorghum growth, being more tolerant to heat and water stress. The results are in agreement with the observations by Turner and Rao (2013) and Gwimbi, Thomas and Hachigonta (2013), which show sorghum gaining in terms of grain yields from higher temperatures in specific regions with lower baseline temperatures (below $20{ }^{\circ} \mathrm{C}$ ). However, Tingem, Rivington, and Bellochi (2009) reported that for the future, little or no change or even 
decreases in maize and sorghum yields are projected in eight agricultural regions of Cameroon. Projections of increased crop yields as a result of climate change have not been explored in Tanzania in particular. Recently, Kilembe et al. (2013) simulated yields for the climates of 2010 (baseline) and 2050 using DSSAT and showed a decrease in sorghum yields ranging from 5 percent to more than 25 percent of the baseline. These results suggest an overall decline in sorghum yields towards midcentury, contrary to results from the present study. This could be attributed to lack of consideration of local environments in terms of weather, soils, varieties and planting dates in the study by Kilembe et al. (2013). On the other hand, the International Model for Policy Analysis of Agricultural Commodities and Trade (IMPACT) showed significant increase in sorghum yields with climate change in Tanzania taking into account technological advancement by 2050. While results from the current study agree and/or disagree with some large scale studies, their strength emanate from the consideration of local crop specific varieties and management practices and the consideration of relevant weather information. In the central zone, the study showed that the magnitude of maize yield decline at least to mid-century is not likely to exceed $25 \%$, results which are in agreement with Moore et al. (2012). In contrast, Mwandosya et al. (1998) projected a decline in maize yields of between 80 and $90 \%$ towards the end of the century.

Considering uncertainties introduced by the crop models' processes, it has been apparent that DSSAT being able to exhibit the effects of [CO2] showed a relatively higher magnitude level of impacts compared with APSIM at highest projected [CO2] i.e. 801 ppm for end century RCP8.5 (Tables 9 and 10). However, some studies have suggested that $\mathrm{C} 4$ plants (e.g., maize and sorghum) do not respond much to elevated levels of $\mathrm{CO}_{2}$ (Sultan et al., 2013). Other studies have further shown that variable responses of the crop models to input parameters, is another source of uncertainty. For example Sadras and Calvino (2001) indicate that CERES model is more sensitive to soil water deficit whereas APSIM is relatively sensitive to physical and chemical characteristics of the soil (Wang et al., 2009).

Table 9. Percentage mean maize yield changes between baseline and three future periods for twenty Global Circulation Models (GCMs) and two Representative Concentration Pathways (RCPs): 4.5 and 8.5. (Shaded figures represent yield change for the five selected GCMs)

\begin{tabular}{|c|c|c|c|c|c|c|c|c|c|c|c|c|}
\hline \multirow{3}{*}{ GCMs } & \multicolumn{6}{|c|}{ DSSAT } & \multicolumn{6}{|c|}{ APSIM } \\
\hline & \multicolumn{2}{|c|}{ NEAR-TERM } & \multicolumn{2}{|c|}{ MIDCENTURY } & \multicolumn{2}{|c|}{ ENDCENTRUY } & \multicolumn{2}{|c|}{ NEAR-TERM } & \multicolumn{2}{|c|}{ MIDCENTURY } & \multicolumn{2}{|c|}{ ENDCENTRUY } \\
\hline & RCP4.5 & $\mathrm{RCP} 8.5$ & RCP4.5 & RCP8.5 & $\mathrm{RCP} 4.5$ & RCP8.5 & RCP4.5 & $\mathrm{RCP} 8.5$ & $\mathrm{RCP} 4.5$ & RCP8.5 & $\mathrm{RCP} 4.5$ & RCP8.5 \\
\hline ACCESS10 & -2.9 & -2.7 & -11.5 & -12.8 & -13.7 & -42.7 & -3.0 & -4.0 & -9.0 & -5.8 & -4.7 & -20.8 \\
\hline BCC-CSM11 & 0.0 & -1.1 & -1.8 & -6.0 & -3.2 & -16.0 & -0.8 & -1.5 & -1.4 & -1.4 & -2.5 & -8.7 \\
\hline BNU-ESM & -0.8 & -0.8 & -1.8 & -4.0 & -4.0 & -14.6 & -5.5 & -4.6 & -5.4 & -7.0 & -7.3 & -12.5 \\
\hline CANES & -0.6 & -1.7 & -3.3 & -5.5 & -4.1 & -18.0 & -1.2 & -1.7 & -3.7 & -3.7 & -5.6 & -12.3 \\
\hline CCSM4 & 2.0 & -1.4 & 1.0 & -2.9 & -0.5 & -11.9 & -0.5 & -1.6 & -3.7 & -4.0 & -3.3 & -10.3 \\
\hline CESMI & 0.0 & -1.6 & -1.1 & -3.6 & -2.4 & -11.9 & -2.8 & -3.1 & -4.4 & -4.3 & -4.9 & -8.2 \\
\hline CSIRO & -3.7 & -2.9 & -10.9 & -13.7 & -17.3 & -36.7 & -4.0 & -2.8 & -5.2 & -5.8 & -7.3 & -19.3 \\
\hline GFDL-ESM2G & -1.7 & -3.3 & -10.9 & 0.1 & 0.1 & -10.1 & -4.6 & -3.6 & -3.6 & -2.7 & 1.4 & -6.5 \\
\hline GFDL-ESM2M & -4.5 & 3.7 & -0.1 & 0.3 & 3.6 & -0.5 & -0.9 & 3.6 & 0.7 & 0.5 & 3.0 & -0.1 \\
\hline HADGEM2-CC & -1.3 & -1.1 & -11.1 & -21.7 & -10.2 & -61.9 & -1.9 & -1.5 & -2.7 & -5.2 & -1.3 & -21.5 \\
\hline HADGEM2-ES & 0.0 & -3.3 & -7.7 & -15.9 & -21.1 & -58.1 & -0.6 & -2.7 & -1.7 & -10.4 & -8.2 & -21.8 \\
\hline INMCM4 & 0.6 & 0.6 & 0.1 & 0.0 & -1.1 & -6.4 & -2.2 & -1.8 & -3.3 & -3.6 & -4.2 & -6.2 \\
\hline IPSL-LR & -1.6 & -2.6 & -4.5 & -11.8 & -10.4 & -46.5 & -1.7 & -3.9 & -0.9 & -2.7 & -4.1 & -17.8 \\
\hline IPSL-MR & -1.9 & -1.2 & -3.6 & -9.9 & -11.7 & -45.1 & -3.1 & -3.2 & -1.3 & -6.9 & -9.6 & -34.4 \\
\hline MIROC5 & -0.1 & -1.3 & -3.2 & -5.2 & -8.5 & -16.0 & 0.2 & -2.3 & -1.7 & -4.1 & -5.9 & -6.0 \\
\hline MIROC-ESM & 1.7 & 3.4 & 0.3 & -2.3 & -2.2 & -19.1 & -3.3 & -3.4 & -6.5 & -8.2 & -8.6 & -17.1 \\
\hline MPI-LR & -0.3 & -0.9 & -2.4 & -8.4 & -2.6 & -31.1 & -2.9 & -2.6 & -3.9 & -3.7 & -2.0 & -15.7 \\
\hline MPI-MR & 0.2 & -3.2 & -4.1 & -11.7 & -4.8 & -33.8 & -4.4 & -3.1 & -5.1 & -5.8 & -5.1 & -16.8 \\
\hline MRI & -5.8 & -2.4 & -7.5 & -6.4 & -5.3 & -15.1 & -3.6 & -1.7 & -9.6 & -5.2 & -7.4 & -11.8 \\
\hline NORESMI & 1.5 & 0.3 & 0.1 & -1.1 & -0.9 & -9.5 & -0.4 & -3.2 & -2.2 & -2.9 & -4.4 & -11.1 \\
\hline Mean & -1.0 & -1.2 & -4.2 & -7.1 & -6.0 & -25.3 & -2.4 & -2.4 & -3.7 & -4.6 & -4.6 & -13.9 \\
\hline
\end{tabular}


Table 10. Percentage mean sorghum yield changes between baseline and three future periods for twenty Global Circulation Models (GCMs) and two Representative Concentration Pathways (RCPs): 4.5 and 8.5. (Shaded figures represent yield change for the five selected GCMs)

\begin{tabular}{|c|c|c|c|c|c|c|c|c|c|c|c|c|}
\hline & \multicolumn{6}{|c|}{ DSSAT } & \multicolumn{6}{|c|}{ APSIM } \\
\hline & \multicolumn{2}{|c|}{ NEAR-TERM } & \multicolumn{2}{|c|}{ MIDCENTURY } & \multicolumn{2}{|c|}{ ENDCENTURY } & \multicolumn{2}{|c|}{ NEAR-TERM } & \multicolumn{2}{|c|}{ MIDCENTURY } & \multicolumn{2}{|c|}{ ENDCENTURY } \\
\hline & $\mathrm{RCP} 4.5$ & RCP8.5 & $\mathrm{RCP} 4.5$ & $\mathrm{RCP} 8.5$ & $\mathrm{RCP} 4.5$ & RCP8.5 & $\mathrm{RCP} 4.5$ & RCP8.5 & $\mathrm{RCP} 4.5$ & $\mathrm{RCP} 8.5$ & $\mathrm{RCP} 4.5$ & $\mathrm{RCP} 8.5$ \\
\hline ACCESS 10 & -6.2 & -6.0 & -2.7 & 6.1 & 4.7 & 13.0 & 7.3 & 7.6 & 9.1 & 10.3 & 11.1 & 10.7 \\
\hline BCC-CSM11 & 6.9 & 8.0 & 12.9 & 15.9 & 12.7 & 10.2 & 7.8 & 7.4 & 9.0 & 9.8 & 7.8 & 8.2 \\
\hline BNU-ESM & 3.3 & 3.7 & 7.1 & 12.6 & 10.9 & 19.7 & 4.3 & 4.2 & 4.4 & 5.4 & 4.7 & 6.2 \\
\hline CANES & 4.5 & 6.5 & 9.4 & 13.1 & 10.1 & 20.8 & 4.0 & 5.8 & 4.6 & 3.9 & 2.4 & 5.3 \\
\hline CCSM4 & 7.3 & 7.1 & 12.8 & 14.6 & 14.3 & 21.4 & 5.7 & 8.3 & 4.6 & 7.6 & 7.9 & 7.9 \\
\hline CESMI & 6.0 & 6.7 & 11.6 & 15.4 & 13.8 & 22.1 & 6.5 & 7.5 & 6.7 & 9.0 & 8.0 & 8.7 \\
\hline CSIRO & 6.2 & 8.1 & 13.0 & 16.1 & 16.2 & 22.9 & 9.2 & 9.2 & 10.8 & 10.8 & 11.0 & 10.0 \\
\hline GFDL-ESM2G & 4.7 & 7.1 & 11.8 & 14.9 & 15.0 & 20.0 & 6.7 & 9.2 & 8.4 & 6.8 & 10.8 & 7.2 \\
\hline GFDL-ESM2M & 3.6 & 7.6 & 9.4 & 13.1 & 8.9 & 15.1 & 8.0 & 5.7 & 8.6 & 7.3 & 3.6 & 3.2 \\
\hline HADGEM2-CC & 7.1 & 8.8 & 14.4 & 16.0 & 17.9 & 25.2 & 7.1 & 7.4 & 9.4 & 8.7 & 9.8 & 11.4 \\
\hline HADGEM2-ES & 10.2 & 7.8 & 14.9 & 18.4 & 16.9 & 24.8 & 7.8 & 7.3 & 9.6 & 10.3 & 9.5 & 5.6 \\
\hline INMCM4 & 4.9 & 5.1 & 9.3 & 12.8 & 2.9 & 18.6 & 6.9 & 6.3 & 7.2 & 6.6 & 7.8 & 7.3 \\
\hline IPSL-LR & 7.8 & 9.0 & 14.9 & 18.1 & 17.1 & 25.8 & 6.3 & 6.7 & 8.8 & 9.7 & 8.7 & 11.7 \\
\hline IPSL-MR & 8.1 & 8.0 & 13.1 & 18.1 & 15.3 & 22.7 & 7.2 & 7.0 & 8.5 & 7.4 & 5.5 & 4.4 \\
\hline MIROC5 & 8.9 & 8.8 & 13.0 & 15.7 & 13.4 & 23.4 & 8.6 & 7.8 & 10.4 & 9.6 & 9.7 & 11.2 \\
\hline MIROC-ESM & 4.5 & 4.5 & 9.1 & 9.9 & 9.5 & 22.4 & 3.8 & 1.5 & 1.6 & 1.2 & -6.7 & 7.6 \\
\hline MPI-ESM-LR & 7.0 & 5.6 & 10.4 & 15.3 & 14.1 & 21.8 & 6.7 & 6.5 & 6.7 & 8.2 & 0.6 & 7.6 \\
\hline MPI-ESM-MR & 4.7 & 7.4 & 10.7 & 15.1 & 14.7 & 23.0 & 5.3 & 8.5 & 6.1 & 9.3 & 0.8 & 9.5 \\
\hline MRI & 2.5 & 5.1 & 7.9 & 12.7 & 10.5 & 19.4 & 8.6 & 8.1 & 6.8 & 7.3 & -0.5 & 6.9 \\
\hline NORESMI & 6.6 & 6.0 & 11.1 & 15.2 & 13.4 & 20.7 & 7.4 & 5.9 & 7.7 & 8.4 & 0.8 & 7.2 \\
\hline Mean & 5.4 & 6.2 & 10.7 & 14.5 & 12.6 & 20.7 & 6.8 & 6.9 & 7.5 & 7.9 & 5.7 & 7.9 \\
\hline
\end{tabular}

\subsection{Effect of Adaptation Options}

To identify adaptation strategies for rainfed sorghum and maize in the study area, four options were evaluated under present and future (mid-century RCP8.5) climate using a subset of five GCMs. Adaptation options combine sowing dates, plant density and inorganic fertilizer applications (Table 6). Mean grain yields of both sorghum and maize from the two crop models under the evaluated adaptation options are shown in Figures 3 and 4. The influence of the improved agro-systems on crop sensitivity to climate change is still a matter of debate (Turner \& Rao, 2013; Sultan et al., 2014). While on the one hand, Turner and Rao (2013) show minimum stress from warming temperatures under the current low-input production systems (no-N fertilizer added) compared to improved systems (with adequate $\mathrm{N}$ fertilization), Sultan et al. (2014) show that increasing fertilizer inputs in the Sahel agricultural system could make it more responsive to climatic stresses and produce more negative impacts (in a relative sense, \%) in crop yields under climate change. Results from both studies suggest that sorghum yields under current smallholders' low-input systems would be resilient or even increase under increasing temperatures. Moreover, the results seem to suggest that micro-dosing with Nitrogen could significantly increase yields even in the hottest and driest locations.

Figure 3 shows that sorghum yields from which $20 \mathrm{~kg} \mathrm{~N} \mathrm{ha}^{-1}$ of inorganic fertiliser is applied, are approximately twice as high as the yields obtained without using fertilizer and are three times higher when $40 \mathrm{~kg} \mathrm{~N} \mathrm{ha}^{-1}$ of fertilizer is used. Considering variability among GCMs, GFDL-ESM and HADGEM2-ES though having contrasting characteristics (Table 7), produced highest mean sorghum yields. At the higher level of fertilizer application $\left(40 \mathrm{~kg} \mathrm{~N} \mathrm{ha}^{-1}\right)$ yield increases projected for sorghum were consistently higher under early planting than with late planting across all GCMs. Simulated sorghum yields, however, indicate that even when planting is delayed by up to one month there is no significant reduction in yields. Traore et al. (2014) similarly reported that a one month delay in planting sorghum and maize did not significantly affect the final yields. Results of simulated maize yields under evaluated adaptation options are shown in Figure 4. Even though rain-fed maize 
production is determined by the adequacy, reliability and timeliness of rainfall, simulated grain yields were increased with inorganic fertilizer application amount. However, farmers are averse to taking risks and therefore, not ready to invest in inputs and improvements if they are not sure of securing good yields in a particular season, as a result low levels of productivity persist (Bezabih \& Di Falco, 2012). Application of fertilizers will become more critical if farmers are to reduce their vulnerability to the impacts of climate change. Besides application of fertilizers, adjustments in planting densities and sowing dates will also be of major importance.

Unlike sorghum, there is an appreciable difference in maize yields among the GCMs with GFDL-ESM giving the highest and HADGEM2-ES giving the lowest yield. This could be due to the effect of projected increase in temperature between the two GCMs (Table 7) where GFDL-ESM projects the lowest increase in average temperature by mid-century whereas the converse is true for HADGEM2-ES. Studies have shown that increased temperatures and change in rainfall patterns will affect major staple cereal food crops such as maize, sorghum and millets because of possible yield decline in future (Zinyengere et al., 2013; Lobell, Banziger, Magorokosho, \& Vivek, 2011). For example, analyses by Lobell et al. (2011) show that each degree day spent above $30{ }^{\circ} \mathrm{C}$ reduces maize grain yield by $1 \%$ under optimal rain-fed conditions, and by $1.7 \%$ under drought conditions in Africa.
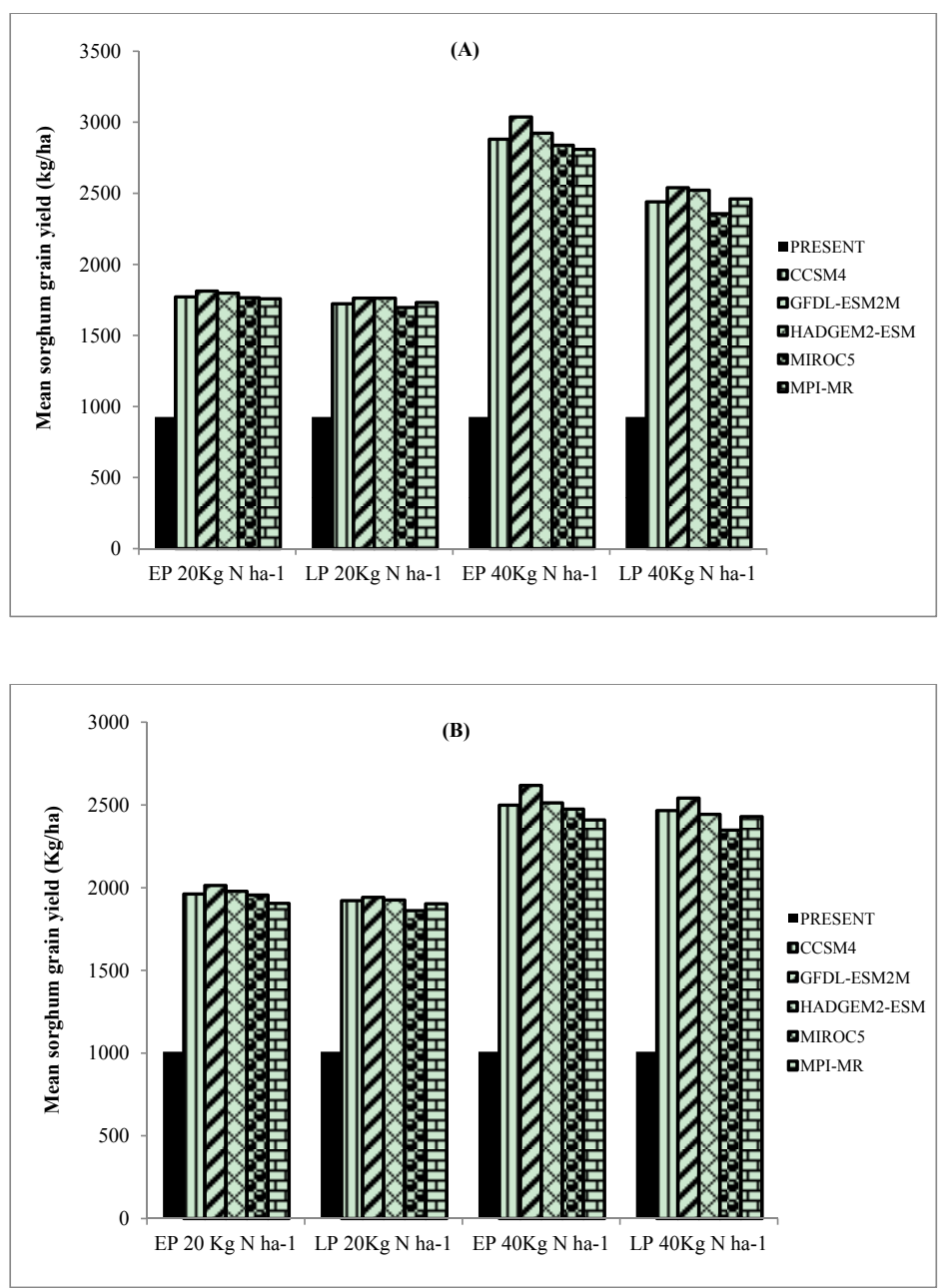

Figure 3. Mean simulated sorghum grain yields under different adaptation options for present (baseline) and midcentury (RCP8.5) using GCMs with APSIM (A) and DSSAT (B)

Note. $\mathrm{EP}=$ Early planting; $\mathrm{LP}=$ Late planting. 

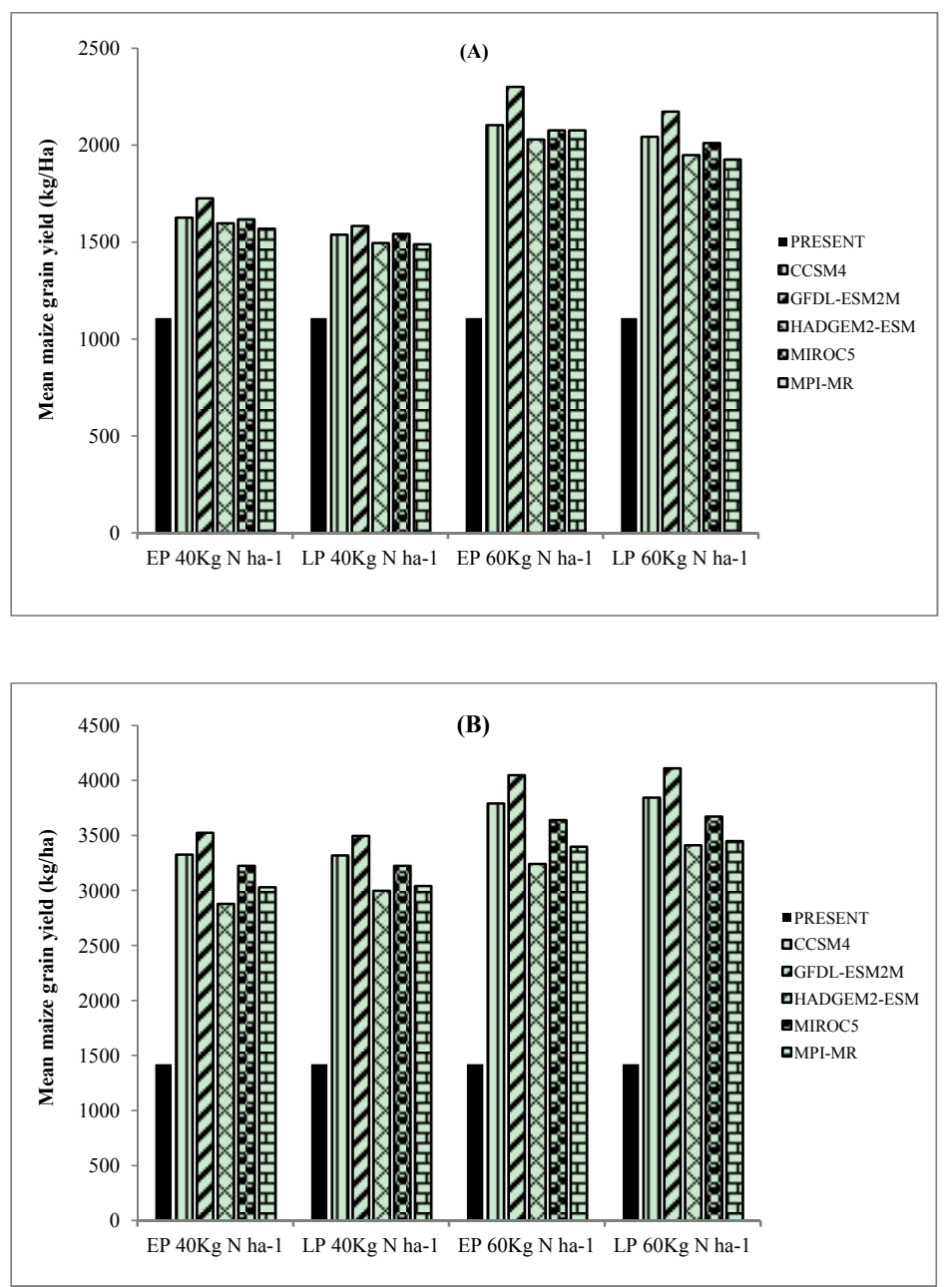

Figure 4. Mean simulated maize grain yields under different adaptation options for present (baseline) and midcentury (RCP8.5) using GCMs with APSIM (A) and DSSAT (B)

Note. $\mathrm{EP}=$ Early planting; $\mathrm{LP}=$ Late planting.

\subsection{Uncertainty on Climate Change Impact and Adaptation Options}

According to the simulation results from the five GCMs, a clear trend that is consistent across crop models and RCPs has been established in as far as yield change is concerned (Tables 9 and 10). Interannual variability of yield under both crop models ranged from a mean CV of $37 \%$ to $55 \%$ for sorghum and $56 \%$ to $70 \%$ for maize (Figure 5). Mean CVs were higher for APSIM than for DSSAT and also higher for maize than for sorghum. The results confirm the uncertainty brought about by the crop models due to differences in parameters (Asseng et al., 2013). The higher range of predictions for maize across GCMs, reflects the uncertainty of climate prediction impacts using GCMs. Similar results were obtained by Moore et al. (2012) who reported between $20 \%$ and 30 $\%$ decrease in maize yields towards mid-century in Morogoro. They attributed the uncertainty to combined effects of greenhouse gas emissions and land cover land use change (LCLUC). Similar results were obtained in Zimbabwe where a GCM and CERES-maize showed that maize yields would decrease by approximately $11-17 \%$, under irrigated and non-irrigated conditions (Stige et al., 2006).

The coefficient of variation (CV) from simulations incorporating agronomic adaptation options is illustrated in Figure 6. While uncertainty remains a factor, a clear trend was established in that yield variability was least influenced by GCMs as shown by the limited differences in CVs, except for HADGEM-ES under DSSAT and early planting scenario which showed increased variability over and above other GCMs (Figure 6D). To a large extent, yield variation appears to have been driven by agronomic adaptation options (Figure 6). Agronomic adaptation strategies influenced uncertainty considerably (low CVs of less than 18\%) as shown in Figure 6D) compared with high $\mathrm{CVs}$ of up to $59 \%$ when simulations were run under current agronomic management practices i.e. mainly without fertilizer application. The results are in agreement with Walker and Schulze (2006) 
who reported reduced variability for treatments using inorganic fertiliser under all the future climate scenarios modelled compared with the $\mathrm{CV}$ of maize yields under previous climate conditions.
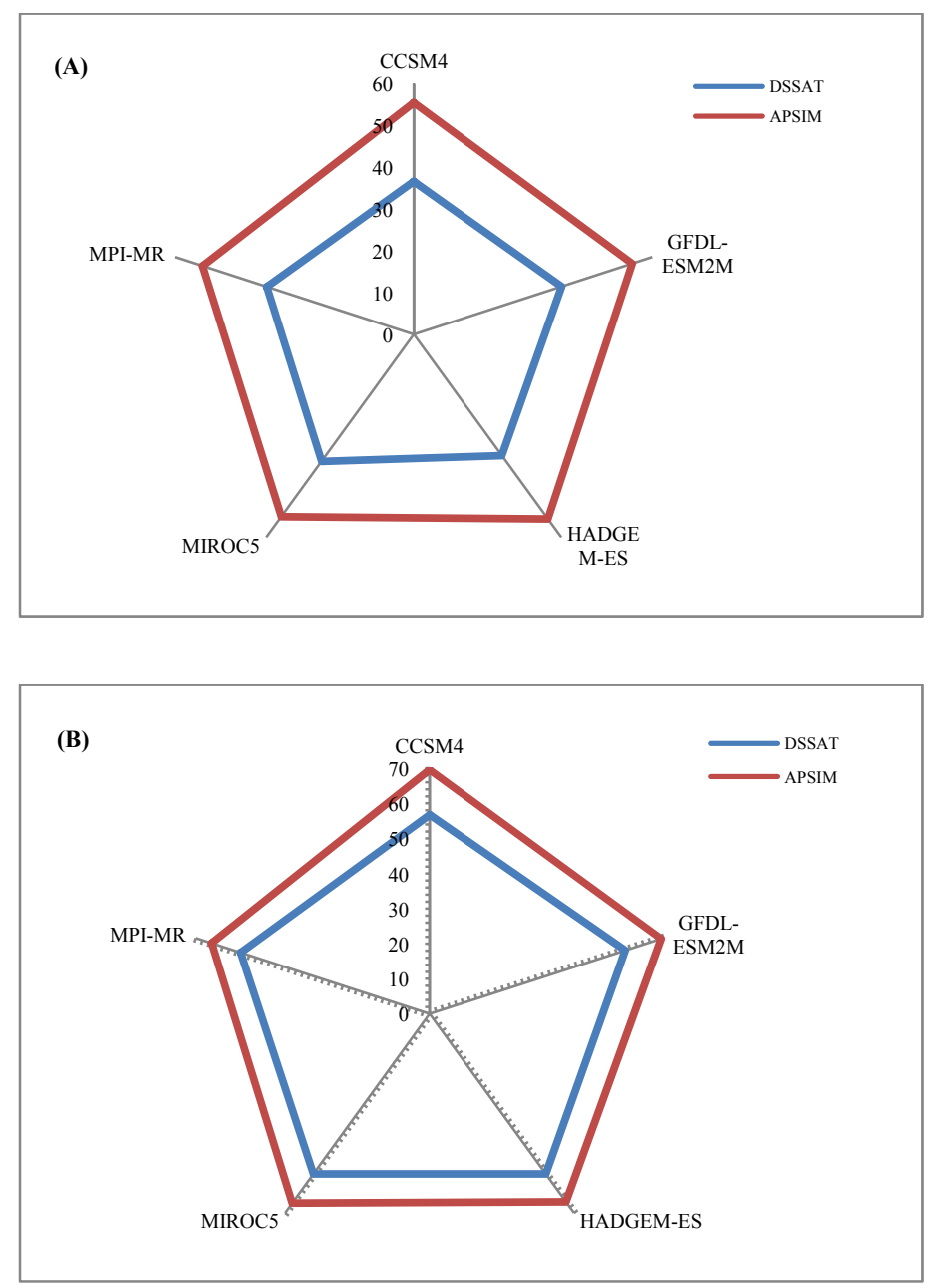

Figure 5. Mean percentage values of coefficient of variation for Sorghum (A) and maize (B) clustered by GCMs

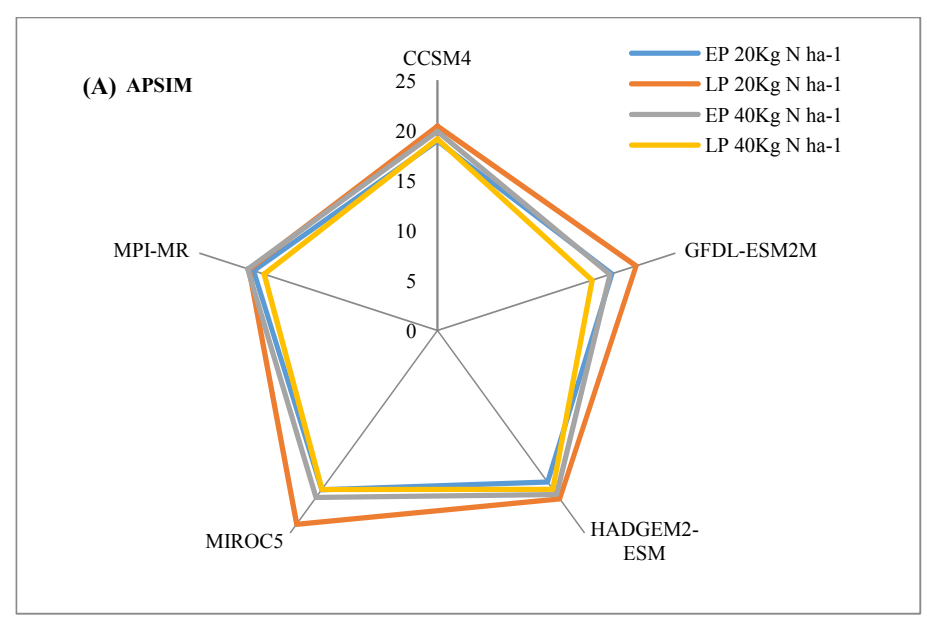



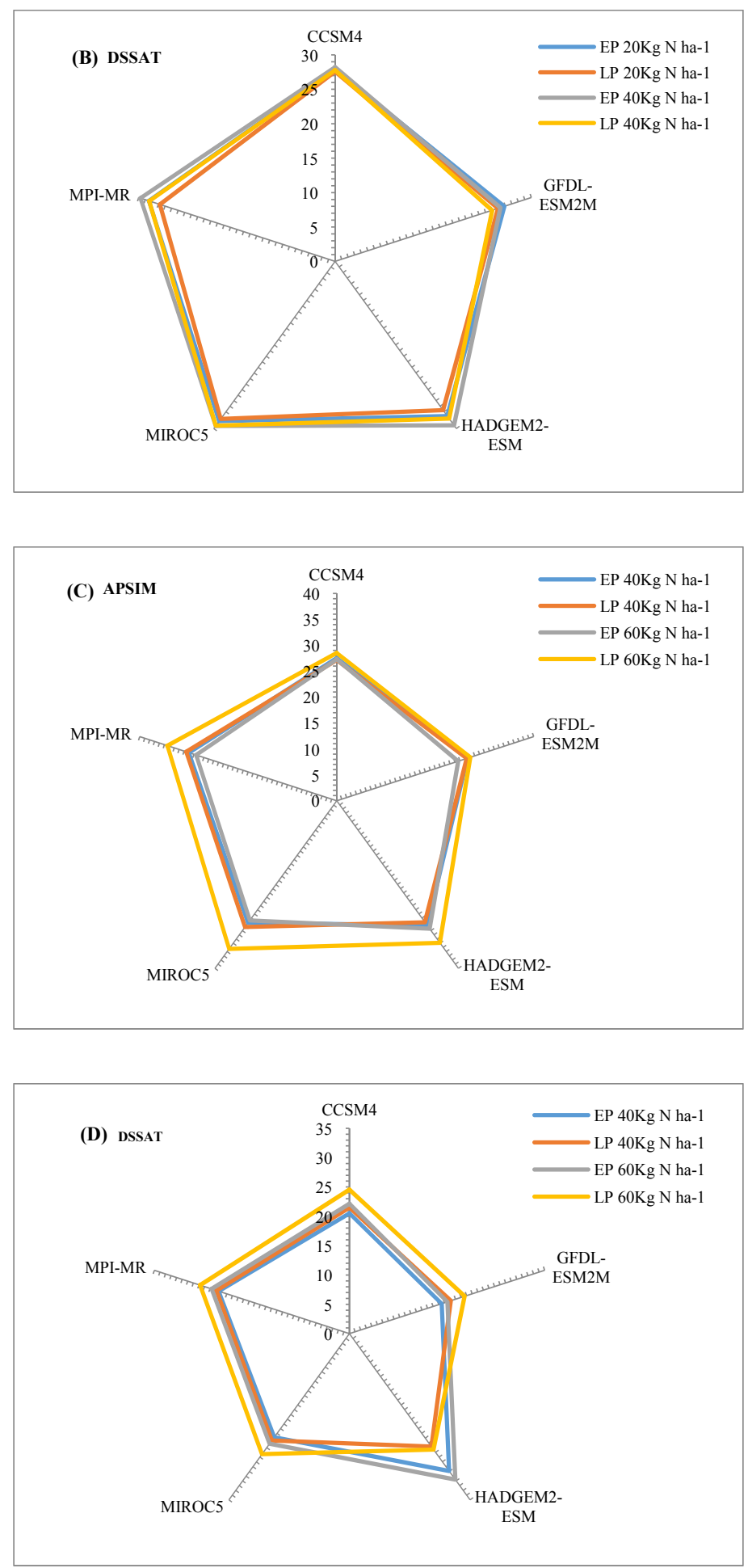

Figure 6. Mean percentage values of coefficient of variation for Sorghum (A \& B) and maize (C\& D) yields with respect to adaptation options clustered by GCMs

\section{Conclusions}

Results from this study demonstrate how crop simulation models coupled with GCMs could play a role in policy decisions with respect to climate change considerations. It has been shown that sorghum yields will consistently increase over different time periods with up to $25 \%$ increase towards the end of the century. On the 
other hand, overall maize yields, by contrast, have been projected to decline. These findings are consistent with those of other studies that have shown similar negative effects on maize, under current varieties and crop management practices, without adaptation strategies. Basic agronomic adaptation options such as fertilizer applications, appropriate planting density and planting dates appear to be ideal for future climate uncertainties. This has a bearing on agricultural plans and policies which may need to be reoriented for enhanced crop productivity.

Despite the uncertainty in crop models and GCMs, the results enhance people's understanding of current climate variability as well as the anticipated climate change which is appropriate for informed agricultural management decisions. Furthermore, the results accentuate the uncertainty that comes from using different models in climate change assessments. All in all the study has contributed to a better understanding of large-area modelling because existing large-area crop models do not currently simulate the non-climatic (e.g. local varieties and crop management practices) determinants of crop yield; factors which also need considerations if useful insights are to be provided for future decision making in a rapidly changing climate.

\section{Acknowledgements}

The Regional Universities Forum for Capacity Building in Agriculture (RUFORUM) is greatly appreciated for funding this PhD study from which this paper is a part. Enhancing Climate Change Adaptation in Agriculture and Water Resources in the Greater Horn of Africa (ECAW) project supported the crop model training with DSSAT while the Agricultural Model Intercomparison and Improvement Project (AgMIP) enabled further training with APSIM and DSSAT.

\section{References}

Ainsworth, E. A., Leaky, A. D. B, Ort, D. R., \& Long, S. P. (2008). FACE-ing the facts: inconsistencies and interdependence among field, chamber and modelling studies of elevated $\left[\mathrm{CO}_{2}\right]$ impacts on crop yield and food supply. New Phytology, 179, 5-9. http://dx.doi.org/10.1111/j.1469-8137.2008.02500.x

Arndt, C., Farmer, W., Strzepek, K., \& Thurlow, J. (2011). Climate change, agriculture and food security in Tanzania (p. 26). Working Paper No. 2011/52 United Nations University-World Institute for Economic Development Research (UNU-WIDER).

Asseng, S., Ewert, F., Rosenzweig, C., Jones, J. W., Hatfield, J. L., Ruane, A. C., ... Wolf, J. (2013). Uncertainty in simulating wheat yields under climate change. Nature Climate Change, 3, 827-832. http://dx.doi.org/10.1038/nclimate1916

Berg, A., de Noblet-Ducoudr'e, N., Sultan, B., Lengaigne, N., \& Guimberteau, M. (2013). Projections of climate change impacts on potential C4 crop productivity over tropical regions. Agricultural and Forest Meteorology, 170, 89-102. http://dx.doi.org/10.1016/j.agrformet.2011.12.003

Bezabih, M., \& Di Falco, S. (2012). Rainfall variability and food crop portfolio choice: Evidence from Ethiopia. Food Security, 4(4), 557-567. http://dx.doi.org/10.1007/s12571-012-0219-7

Challinor, A. J., Watson, J., Lobell, D. B., Howden, S. M., Smith, D. R., \& Chhetri, N. (2014). A meta-analysis of crop yield under climate change and adaptation. Nature Climate Change, 4, 287-291. http://dx.doi.org/10.1038/nclimate2153

Falloon, P., Challinor, A., Dessai, S., Hoang, L., Johnson, J., \& Koehler, A. (2014). Ensembles and uncertainty in climate change impacts. Frontiers in Environmental Science, 2(Article 33), 1-7. http://dx.doi.org/10.3389/fenvs.2014.00033

Gwimbi, P., Thomas, T. S., \& Hachigonta, S. (2013). Assessing the vulnerability of agriculture to climate change in Lesotho. In S. Hachigonta, G. C. Nelson, T. S. Thomas, \& L. M. Sibanda (Eds.), Southern African Agriculture and Climate Change: A Comprehensive Analysis. International Food Policy Research Institute, Washington, D.C. http://dx.doi.org/10.2499/9780896292086

Hatfield, L., Boote, K. J., Kimball, B. A., Ziska, L. H., Izaurralde, R. C., Ort, D., ... Wolfe, D. (2011). Climate Impacts on Agriculture: Implications for Crop Production. Agronomy Journal, 103, 351-370. http://dx.doi.org/10.2134/agronj2010.0303

Hempel, S., Frieler, K., Warszawski, L., Shewe, J., \& Piontek, F. (2013). A trend- reserving bias correction - the ISI-MIP approach. Earth Systems Dynamics, 4, 219-236. http://dx.doi.org/10.5194/esd-4-219-2013

Ingram, J. S. I., Gregory, P. J., \& Izac, A. M. (2008). The role of agronomic research in climate change and food security policy. Agriculture Ecosystems and Environment, 126, 1-12. 
http://dx.doi.org/10.1016/j.agee.2008.01.009

IPCC. (2013). Summary for Policymakers. In T. F. Stocker, D. Qin, G.-K. Plattner, M. Tignor, S. K. Allen, J. Boschung, A. Nauels, Y. Xia, V. Bex \& P. M. Midgley (Eds.), Climate Change 2013: The Physical Science Basis. Contribution of Working Group I to the Fifth Assessment Report of the Intergovernmental Panel on Climate Change. Cambridge University Press, Cambridge, United Kingdom and New York, NY, USA.

Jones, J. W., Hoogenboom, G., Porter, C. H., Boote, K. J., Batchelor, W. D., Hunt, L. A., ... Ritchie, J. T. (2003). The DSSAT cropping system model. European Journal of Agronomy, 18, 235-265. http://dx.doi.org/10.1016/S1161-0301(02)00107-7

Keating, B. A., Carberry, P. S., Hammer, G. L., Probert, M. E., Robertson, M. J., Holzworth, D., ... Smith, C. J. (2003). An overview of APSIM, a model designed for farming systems simulation. European Journal of Agronomy, 18, 267-288. http://dx.doi.org/10.1016/S1161-0301(02)00108-9

Kilembe, C., Thomas, T. S., Waithaka, M., Kyotalimye, M., \& Tumbo, S. (2013). Tanzania. In M. Waithaka, G. C. Nelson, T. S. Thomas \& M. Kyotalimye (Eds.), East African Agriculture and Climate Change: A Comprehensive Analysis (pp. 313-343). IFPRI, Washington, DC.

Knox, J., Hess, T., Daccache, A., \& Wheeler, T. (2012). Climate change impacts on crop productivity in Africa and South Asia. Environmental Research Letters, 7(034032), 8.

Leenaars, J. G. B. (2012). Africa Soil Profiles Database Version 1.0. A compilation of georeferenced and standardized legacy soil profile data for Sub Saharan Africa (with dataset). ISRIC report 2012/03. Africa Soil Information Service (AfSIS) project and ISRIC-World Soil Information, Wageningen, the Netherlands

Lobell, D. B., Burke, M. B., Tebaldi, C., Mastrandrea, M. D., Falcon, W. P., \& Naylor, R. L. (2008). Prioritizing climate change adaptation needs for food security in 2030. Science, 319, 607-610. http://dx.doi.org/10.1126/science.1152339

Lobell, D. B., Bänziger, M., Magorokosho, C., \& Vivek, B. (2011). Nonlinear heat effects on African maize as evidenced by historical yield trials. Nature Climate Change, 1, 42-45. http://dx.doi.org/10.1038/nclimate1043

Lyon, B., \& DeWitt, D. G. (2012). A recent and abrupt decline in the East African long rains. Geophysical Research Letters, 39(2). http://dx.doi.org/10.1029/2011GL050337

Matari, E. E., Chang'a, L. B., Chikojo, G. E., \& Hyera, T. (2008). Climate change scenarios development for second national communication, Tanzania. TMA Research Journal, 1, 8-18.

McSweeney, C., New, M., \& Lozano, G. (2010). The UNDP Climate change country profiles, Tanzania. Improving the accessibility of observed and projected climate information for studies of climate change in developing countries. Retrieved from http://country-profiles.geog.ox.ac.uk

Moore, N., Alagarswamy, G., Pijanowski, B., Thornton, P., Lofgren, B., Olson, J., ... Qi, J. (2012). East African food security as influenced by future climate change and land use change at local to regional scales. Climatic Change, 110, 823-844. http://dx.doi.org/10.1007/s10584-011-0116-7

Moss, R. H., Edmonds, J. A., Hibbard, K. A., Manning, M. R., Rose, S. K., van Vuuren, D. P., ... Wilbanks, T. J. (2010). The next generation of scenarios for climate change research and assessment. Nature, 463, 747-756. http://dx.doi.org/10.1038/nature08823

Mourice, S. K., Rweyemamu, C. L., Tumbo, S. D., \& Amuri, N. (2014). Maize Cultivar Specific Parameters for Decision Support System for Agrotechnology Transfer (DSSAT) Application in Tanzania. American Journal of Plant Sciences, 5, 821-833. http://dx.doi.org/10.4236/ajps.2014.56096

Mwandosya, M. J., Nyenzi, B. S., \& Luhanga, M. L. (1998). The Assessment of Vulnerability and Adaptation to Climate Change Impacts in Tanzania. Dar-es-Salaam, Tanzania: Centre for Energy, Environ. Sci. Technol. (CEEST).

NBS. (2012). Tanzania National Panel Survey Report Wave 2, 2010 -2011, Living Standards Measurements Survey. National Bureau of Statistics, Dar-es-Salaam, Tanzania.

Paavola, J. (2003). Vulnerability to Climate Change in Tanzania: Sources, Substance and Solutions. A paper presented at the inaugural workshop of Southern Africa Vulnerability Initiative (SAVI) in Maputo, Mozambique June 19-21. 
Porter, J. R., \& Semenov, M. A. (2005). Crop responses to climatic variation. Philosophical Transactions of the Royal Society, B(360), 2021-5. http://dx.doi.org/10.1098/rstb.2005.1752

Ramirez-Villegas, J., Challinor, A, Thornton, P., \& Jarvis, A. (2013). Implications of regional improvement in global climate models for agricultural impact research. Environmental Research Letters, 8, 12. http://dx.doi.org/10.1088/1748-9326/8/2/024018.

Riahi, K., Grübler, A., \& Nakicenovic, N. (2007). Scenarios of long-term socio-economic and environmental development under climate stabilization. Technological Forecasting and Social Change, 74, 887-935. http://dx.doi.org/10.1016/j.techfore.2006.05.026

Rosenzweig, C., Elliott, J., Deryng, D., Ruane, A. C., Müllere, C., Arneth, A., ... Jones, J. W. (2014). Assessing agricultural risks of climate change in the 21 st century in a global gridded crop model intercomparison. Proceeding of National Academy of Sciences. http://dx.doi.org/10.1073/pnas. 1222463110

Rosenzweig, C., Jones, J., Hatfield, J., Antle, J., Ruane, A., Boote, K., ... Mutter, C. (2013b). AgMIP Guide for Regional Integrated Assessments: Handbook of Methods and Procedures Version 5.0.

Rosenzweig, C., Jones, J. W., Hatfield, J. L., Ruane, A. C., Boote, K. J., Thorburn, P., ... Winter, J. M. (2013a). The agricultural model intercomparison and improvement project (AgMIP). Protocols and pilot studies. Agriculture and Forest Meteorology, $170, \quad 182$. http://dx.doi.org/10.1016/j.agrformet.2012.09.011

Rötter, R. P., Carter, T. R., Olesen, J. E., \& Porter, J. R. (2011). Crop-climate models need an overhaul. Nature Climate Change, 1, 175-177. http://dx.doi.org/10.1038/nclimate1152

Rowhani, P., Lobell, D. B., Linderman, M., \& Ramankutty, N. (2011). Climate variability and crop production in Tanzania. Agricultural and Forest Meteorology, 151, 449-460. http://dx.doi.org/10.1016/j.agrformet.2010.12.002

Ruane, A. C., Cecil, L. D., Horton, R. M., Gordon, R., McCollum, R., Brown, D., ... Rosenzweig, C. (2013). Climate change impact uncertainties for maize in Panama: Farm information, climate projections, and yield sensitivities. Agriculture and Forest Meteorology, 170, 132-145. http://dx.doi.org/10.1016/j.agrformet.2011.10.015

Ruiz-Ramos, M., \& Minguez, M. I. (2010). Evaluating uncertainty in climate change impacts on crop productivity in the Iberian Peninsula. Climate Research, 44, 69-82. http://dx.doi.org/10.3354/cr00933

Rurinda, J., Mapfumo, P., van Wijk, M. T., Mtambanengwe, F., Rufino, M. C., Chikowo, R., \& Giller, K. E. (2014). Comparative assessment of maize, finger millet and sorghum for household food security in the face of increasing climatic risk. European Journal of Agronomy, 55, 29-41. http://dx.doi.org/10.1016/j.eja.2013.12.009

Sadras, V. O., \& Calviño, P. A. (2001). Quantification of grain yield response to soil depth in soybean, maize, sunflower, and wheat. Agronomy Journal, 82, 577-583. http://dx.doi.org/10.2134/agronj2001.933577x

Schlenker, W., \& Lobell, D. B. (2010). Robust negative impacts of climate change on African agriculture. Environmental Research Letters, 1, 14010. http://dx.doi.org/10.1088/1748-9326/5/1/014010

Shongwe, M. E., van Oldenborgh, G. J., van den Hurk, B., \& van Aalst, M. (2011). Projected changes in mean and extreme precipitation in Africa under global warming. Part II: East Africa. Journal of Climate, 24(14), 3718-3733. http://dx.doi.org/10.1175/2010JCLI2883.1

Stige, L. C., Stave, J., Chan, K. S., Ciannelli, L., Pretorelli, N., Glantz, M., ... Stenseth, N. C. (2006). The effect of climate variation on agro-pastoral production in Africa. Proceedings of the National Academy of Science, 103, 3049-3053.

Sultan, B., Guan, K., Kouressy, M., Biasutti, M., Piani, C., Hammer, G. L., ... Lobell, D. B. (2014). Robust features of future climate change impacts on sorghum yields in West Africa. Environmental Research Letters, 9(104006), 13. http://dx.doi.org/10.1088/1748-9326/9/10/104006

Sultan, B., Roudier, P., Quirion, P., Alhassane, A., Muller, B., Dingkuhn, M., ... Baron, C. (2013). Assessing climate change impacts on sorghum and millet yields in the Sudanian and Sahelian savannas of West Africa. Environmental Research Letters, 8, 14040. http://dx.doi.org/10.1088/1748-9326/8/2/014040.

Taylor, K. E., Stouffer, R. J., \& Meehl, G. A. (2012). An overview of CMIP5 and the experiment design. Bulletin of American Meteorological Society, 93, 485-98. http://dx.doi.org/10.1175/BAMS-D-11-00094.1 
Taylor, R. G., Todd, M. C., Kongola, L., Maurice, L., Nahozya, E., Sanga, H., \& MacDonald, A. M. (2013). Evidence of the dependence of groundwater resources on extreme rainfall in East Africa. Nature Climate Change, 3, 374-378. http://dx.doi.org/10.1038/nclimate1731

Thompson, H. E., Berrang-Ford, L., \& Ford, J. D. (2010). Climate Change and Food Security in Sub- Saharan Africa: A Systematic Literature Review. Sustainability, 2, 2719-2733. http://dx.doi.org/10.3390/su2082719

Thornton, P. K., Jones, P. G., Alagarswamy, A., \& Andresen, J. (2009). Spatial variation of crop yield responses to climate change in East Africa. Global Environmental Change, 19, 54-65. http://dx.doi.org/10.1016/j.gloenvcha.2008.08.005

Thornton, P. K., Jones, P. G., Alagarswamy, G., Andresen, J., \& Herrero, M. (2010). Adapting to climate change: Agricultural system and household impacts in East Africa. Agricultural Systems, 103, $73-82$. http://dx.doi.org/10.1016/j.agsy.2009.09.003

Thornton, P. K., Jones, P. G., Ericksen, P. J., \& Challinor, A. J. (2011). Agriculture and food systems in subSaharan Africa in a $4{ }^{\circ} \mathrm{C}+$ world. Philosophical Transactions of the Royal Society, 369, 117-136.

Tingem, M., Rivington, M., \& Bellocchi, G. (2009). Adaptation assessment for crop production in response to climate change in Cameroon. Agronomy Sustainable Development, 29, $247-256$. http://dx.doi.org/10.1051/agro:2008053

Traore, B., van Wijk, M. T., Descheemaeker, K., Corbeels, M., Rufino, M. C., \& Giller, K. E. (2014). Evaluation of climate adaptation options for Sudano-Sahelian cropping systems. Field Crops Research, 156, 63-75. http://dx.doi.org/10.1016/j.fcr.2013.10.014

Turner, N. C., \& Rao, K. P. C. (2013). Simulation analysis of factors affecting sorghum yield at selected sites in eastern and southern Africa, with emphasis on increasing temperatures. Agricultural Systems, 121, 53-62. http://dx.doi.org/10.1016/j.agsy.2013.06.002

URT. (2007). United Republic of Tanzania, National Adaptation Programme of Action (NAPA). Division of Environment, Vice President's Office, Dar es Salaam.

Waha, K., Müller, C., \& Rolinski, C. (2013). Separate and combined effects of temperature and precipitation change on maize yields in sub-Saharan Africa for mid- to late-21st century. Global Planetary Change, 106, 1-12. http://dx.doi.org/10.1016/j.gloplacha.2013.02.009

Wambura, F., Ngongolo, H., Mlonganile, P., Sangalugembe, C., \& Tumbo, S. (2014). CMIP5 climate change projections for Tanzania. A paper presented at the International Conference on Reducing Climate Change Challenges through Forestry and other Land Use practices $1^{\text {st }}-3^{\text {rd }}$ April 2014, Nashera Hotel, Morogoro, Tanzania.

Wang, J., Wang, E. L., Luo, Q. Y., \& Kirby, M. (2009). Modelling the sensitivity of wheat growth and water balance to climate change in Southeast Australia. Climatic Change, 96, 79-96. http://dx.doi.org/10.1007/s10584-009-9599-x

Watson, J., \& Challinor, A. (2013). The relative importance of rainfall, temperature and yield data for a regional-scale crop model. Agriculture and Forest Meteorology, 170, 47-57. http://dx.doi.org/10.1016/j.agrformet.2012.08.001

White, J. W., Hoogenboom, G., Kimball, B. A., \& Wall, G. W. (2011). Methodologies for simulating impacts of climate change on crop production. Field Crops Research, 124, 357-368. http://dx.doi.org/10.1016/j.fcr.2011.07.001

Yao, F. M., Qin, P. C., Zhang, J. H., Lin, E., \& Boken, V. (2011). Uncertainties in assessing the effect of climate change on agriculture using model simulation and uncertainty processing methods. Chinese Science Bulletin, 56, 729-737. http://dx.doi.org/10.1007/s11434-011-4374-6.

Zinyengere, N., Crespo, O., \& Hachigonta, S. (2013). Crop response to climate change in southern Africa: A comprehensive review. Global and Planetary Change, 111, 118-126. http://dx.doi.org/10.1016/j.gloplacha.2013.08.010

Zinyengere, N., Crespo, O., Hachigonta, S., \& Tadross, M. (2014). Local impacts of climate change and agronomic practices on dry land crops in Southern Africa. Agriculture, Ecosystems and Environment, 197, 1-10. http://dx.doi.org/10.1016/j.agee.2014.07.002 


\section{Copyrights}

Copyright for this article is retained by the author(s), with first publication rights granted to the journal.

This is an open-access article distributed under the terms and conditions of the Creative Commons Attribution license (http://creativecommons.org/licenses/by/3.0/). 